\title{
INTEGRITI DALAM PERKHIDMATAN AWAM PADA ERA TUNKU ABDUL RAHMAN PUTRA AL-HAJ, 1957-1970
}

\author{
Loganathan Veerasamy \\ Sivachandralingam Sundara Raja
}

\begin{abstract}
The efficient administration of any country depends on government officials of high integrity. Integrity as a concept combines rectitude of conduct, purity of motive, moderation and balance in dealing with issues as well as transparency. Integrity is relevant in the life of a nation as it is in the daily life of an individual. Malaysia's success in this respect is attributable to leaders and officials of high integrity who have been administering and leading the nation through difficult times from the pre-independence era until present times. In this context, it is significant to emphasise the role played by Tunku Abdul Rahman, the first Prime Minister of the Federation of Malaya in laying the foundation of a civil service that upholds integrity. This is reflected in the selective appointment of civil servants whose sense of integrity helps to build a positive image of the nation. Tunku had indeed contributed greatly towards forging a model civil service.
\end{abstract}

\section{Pengenalan}

Malaysia merupakan sebuah negara yang mengamalkan sistem Kerajaan Demokrasi Berparlimen. Rakyat di negara ini mempunyai hak untuk memilih kerajaan secara adil, telus dan bertanggungjawab. Kerajaan yang dipilih mempunyai kuasa eksekutif untuk menyampaikan perkhidmatan yang terbaik kepada rakyat. Kerajaan yang diberi mandat 
untuk memerintah juga mempunyai tanggungjawab dalam menjana dan mengekalkan pertumbuhan ekonomi; menjaga keamanan dan ketenteraman serta menyediakan kemudahan infrastruktur awam kepada rakyat. Untuk merealisasikan tanggungjawab tersebut, kerajaan membentuk perkhidmatan awam sebagai jentera pelaksana program dan dasar-dasar kerajaan. Perkhidmatan kerajaan atau lebih dikenali sebagai perkhidmatan awam merupakan jentera kerajaan terbesar yang dibentuk untuk menyampaikan perkhidmatan untuk seluruh rakyat.

Memandangkan peranan dan tanggungjawab perkhidmatan awam sangat penting, pada awal tahun 60-an kerajaan di bawah kepimpinan Tunku Abdul Rahman memperkenalkan dasar MeMalaysiakan perkhidmatan awam. Di bawah dasar tersebut kerajaan mengeluarkan arahan kepada Jabatan Perkhidmatan Awam yang merupakan tulang belakang kepada pentadbiran persekutuan untuk melantik pegawai dan kakitangan warganegara Malaysia yang bersesuaian dan berkelayakan bagi mengambilalih jawatan-jawatan dalam perkhidmatan awam yang selama ini disandang oleh pegawai-pegawai 'expatriate'. Perkhidmatan awam yang ingin dibentuk oleh pemimpin negara sama sekali berbeza jika dibandingkan dengan perkhidmatan awam di bawah pentadbiran British.

Menurut Tun Abdul Razak, perkhidmatan awam di bawah kerajaan British hanya berfungsi sebagai perkhidmatan penjagaan dan penyelenggaraan. Perkhidmatan tersebut lebih menumpukan kepada kerja rutin untuk mengekalkan 'status quo' dan menjalankan pembangunan berdasarkan keperluan. Senario tersebut mula berubah di bawah kepimpinan Tunku Abdul Rahman yang melihat perkhidmatan awam sebagai agensi regulatory, pemangkin serta fasilitator kepada pembangunan negara. Perkhidmatan awam merupakan jentera pelaksana semua program dan rancangan pembangunan bagi kepentingan segenap lapisan masyarakat.

\section{Perkembangan Perkhidmatan Awam}

Sejarah perkembangan perkhidmatan awam Malaysia ${ }^{1}$ dan penerapan integriti dapat dikesan di Negeri-negeri Selat dan Negeri-Negeri Melayu semenjak zaman penjajahan British. Perkhidmatan awam muncul sebagai jentera pentadbiran penting bagi menjana ekonomi untuk kerajaan British. Menyedari kepentingannya, sejak bertapak di Negeri-negeri Melayu, kerajaan British mengambil pelbagai langkah bagi memastikan jentera pentadbiran sentiasa berada pada tahap yang baik dan berkualiti. Antara langkah yang diperkenalkan termasuk calon-calon perkhidmatan awam mesti berasal daripada keluarga yang bermoral tinggi dan aktif dalam sukan serta mempunyai pengalaman 
bermastautin di kawasan tropika. ${ }^{2}$ Dalam masa yang sama setiap calon mesti mempunyai kelayakan akademik di peringkat universiti dan berumur di antara dua puluh sehingga dua puluh tiga tahun. ${ }^{3}$.

Penerapan integriti dalam perkhidmatan awam menyerlah di Negeri-negeri Melayu apabila pentadbir British menubuhkan Majlis Mesyuarat Negeri (MMN) pada 1874, untuk mengenal pasti perasaan atau pandangan masyarakat tempatan terhadap pembaharuan yang diperkenalkan oleh British dan mengambil langkah penambahbaikan untuk mengekalkan sokongan masyarakat tempatan. ${ }^{4}$ Selepas Persekutuan dibentuk pada 1896, British mengambil langkah membentuk perkhidmatan awam yang cekap dan teratur untuk menarik lebih ramai pedagang dan modal asing ke Negeri-negeri Melayu Bersekutu. ${ }^{5}$ Sebagai langkah awal, British memperkenalkan Skim Perkhidmatan Awam Persekutuan yang merupakan satu strategi ke arah penambahbaikan perkhidmatan awam di Negeri-negeri Melayu Bersekutu.$^{6}$ Menjelang tahun 1910, perkhidmatan awam Tanah Melayu mengalami perubahan besar. Ketidakinginan pegawai-pegawai Eropah untuk berkhidmat di Negeri-negeri Melayu dan kepesatan kemajuan perdagangan di Negeri-negeri Melayu telah menyegerakan proses pengambilan calon-calon Melayu dalam perkhidmatan awam. ${ }^{7}$

Menjelang tahun 1955, peranan dan tanggungjawab perkhidmatan awam telah bertambah dan menjadi cabaran kepada pentadbir British untuk menjaga imej dan integriti perkhidmatan awam. Untuk memelihara integriti perkhidmatan awam terutamanya tentang cara mengurangkan kesempatan melakukan perbuatan rasuah, pentadbir British telah menubuhkan satu Suruhanjaya pada tahun 1955dengan dipengerusikan oleh E.N. Taylor. ${ }^{8}$ Lapan tokoh yang berpengalaman telah dilantik sebagai ahli Suruhanjaya dalam usaha memartabatkan integriti perkhidmatan awam. Tokoh-tokoh ini ialah E.N. Taylor, Yong Shook Lin, V.M.N. Menon, Hussein Onn, G.Shelley, Raja Musa bin Raja Mahadi, A.C. Smith, J.G. Black, A.M.F. Webb. ${ }^{9}$

Integriti dalam perkhidmatan awam bertambah baik selepas Tunku Abdul Rahman dilantik sebagai Perdana Menteri pertama Malaysia pada tahun 1957. Beliau yang memikul tanggungjawab untuk mentadbir negara secara adil dan saksama berlandaskan Perlembagaan Persekutuan, ${ }^{10}$ berazam mentransformasikan negara dan mempertingkatkan kualiti hidup rakyat dengan sokongan dan kerjasama perkhidmatan awam yang diwarisi daripada British. Walaupun perkhidmatan awam British bersistematik, masih terdapat pengamalan berbentuk regulatory, seperti mengutip cukai, memelihara sistem dan menjaga keamanan yang tidak sesuai dan mampu memajukan ekonomi negara. ${ }^{11}$ Selepas merdeka, kerajaan pimpinan Tunku mengambil pelbagai langkah untuk menyusun semula jentera 
perkhidmatan awam dan sumber manusia supaya lebih efektif sebagai penggubal, perancang dan pelaksana program pembangunan khususnya di luar bandar. ${ }^{12}$ Dalam hal ini, Tunku percaya transformasi perkhidmatan awam berteraskan integriti boleh membantu mencapai matlamat tersebut. ${ }^{13}$

\section{Penubuhan Suruhanjaya Perkhidmatan Awam}

Usaha pertama yang diambil oleh Tunku untuk menerapkan integriti dalam perkhidmatan awam adalah dengan menyokong penubuhan Suruhanjaya Perkhidmatan Awam (SPA), pada 31 Ogos 1957, sebagaimana termaktub dalam Perkara 144(1), Perlembagaan Persekutuan. ${ }^{14}$ Persidangan Perlembagaan Persekutuan yang berlangsung di London pada penghujung bulan Januari dan Februari 1956, bersetuju atas penubuhan badan tersebut. ${ }^{15}$ Ketika menyentuh tentang perkara ini, Tunku berkata:

...Alliance Government attached to maintaining an efficient and contented
civil service. To this end the Service must feel that it is not subject to political
interference and that it can tender advice without fear of the consequences.
Only in this way can it be expected to attract into the Service and retain the
men and women of the high calibre that will be needed. At the Constitutional
Conference held in London in January and February 1956, it was agreed
that the most generally accepted method of achieving this end was by setting
up an independent Public Service Commission ... ${ }_{16}$

Kenyataan Tunku jelas membuktikan kerajaan tidak mahu bertolak ansur dalam perjuangan untuk membentuk perkhidmatan awam yang efisien dan seterusnya memantapkan integriti dalam perkhidmatan awam. Matlamat murni tersebut boleh dicapai dengan penubuhan SPA yang berperanan sebagai badan bebas untuk melantik calon-calon yang mempunyai kelulusan akademik, memiliki nilai-nilai murni dan mempunyai kerakyatan Persekutuan untuk berkhidmat dalam perkhidmatan awam. Semua calon yang dilantik akan menerima layanan yang sama tanpa campur tangan atau tekanan politik. ${ }^{17}$ Dalam hal ini, Tunku menjelaskan pendirian kerajaan bahawa tugas ahli politik bukanlah untuk campur tangan dalam hal-hal berkaitan dengan perkhidmatan awam; sebaliknya kerajaan pimpinan beliau bertekad untuk membentuk perkhidmatan awam yang bebas, adil dan berkecuali. ${ }^{18}$ Menurut Tunku:

...ada kalanya orang datang kepada saya atau menteri minta kerja. Ada yang meminta naik pangkat, ada yang meminta tukar tempat.... semua ini tidak perlu dihadapkan kepada menteri sebab kita telah menubuhkan Public Service Commission.... ${ }^{19}$ 
Selain itu, prinsip-prinsip penubuhan SPA yang dibentangkan dalam Persidangan Perlembagaan Persekutuan yang diadakan di London pada tahun 1956, mencerminkan kesungguhan Tunku untuk memartabatkan integriti dalam perkhidmatan awam. Antara prinsip yang dibentangkan ialah Pengerusi Suruhanjaya haruslah seorang yang berwibawa dan jujur dalam erti kata lain beliau boleh dipercayai dan boleh diberi kuasa mutlak untuk membuat keputusan. Ahli-ahli yang dipilih untuk menerajui Suruhanjaya tersebut mesti berupaya bekerjasama secara kumpulan dan bukannya bercakap untuk kepentingan diri sendiri. Suruhanjaya perlu berfungsi secara bebas tanpa pengaruh mana-mana badan atau parti politik dan bertanggungjawab dalam pelantikan, kenaikan pangkat dan menjalankan kawalan tatatertib ke atas anggotaanggota perkhidmatan awam. ${ }^{20}$ Setiap prinsip tersebut mencerminkan kesungguhan Tunku untuk membentuk jentera perkhidmatan awam yang berintegriti.

SPA memainkan peranan penting untuk melantik penjawat awam terbaik dari segi kelayakan akademik, sahsiah dan peribadi unggul serta memiliki kompetensi yang sesuai untuk mengisi sesuatu jawatan dalam perkhidmatan awam. ${ }^{21}$ Penubuhan SPA juga mencerminkan merit birokrasi organisasi kerajaan bagi menjamin taraf perkhidmatan, kenaikan pangkat dan pengaplikasian disiplin tanpa diskriminasi dalam kalangan kakitangan. ${ }^{22}$ Pengamalan sistem yang telus dalam SPA, membantu melantik tenaga modal insan yang berkualiti unggul dalam perkhidmatan awam dan mampu memainkan peranan untuk merancang dan melaksana rancangan pembangunan bagi meningkatkan kualiti hidup rakyat. ${ }^{23}$

Dengan penubuhan SPA, kerajaan pimpinan Tunku telah berjaya menginstitusikan integriti, kredibiliti dan akauntabiliti dalam perkhidmatan awam. Setelah menginstitusikan integriti, Tunku telah menggunakan majlis rasmi kerajaan sebagai platform untuk menerapkan integriti dalam kalangan pegawai-pegawai perkhidmatan awam.

\section{Agenda Integriti Kepada Pegawai Perkhidmatan Awam}

Tunku telah menggunakan majlis-majlis rasmi kerajaan yang dianjurkan untuk pegawai-pegawai kerajaan sebagai platform untuk meningkatkan kesedaran tentang kepentingan pengamalan integriti dalam kalangan pegawai perkhidmatan awam. Usaha murni itu dapat disaksikan ketika Tunku menyampaikan ucapan kepada pegawai-pegawai kerajaan yang mengikuti Kursus Perkhidmatan Eksekutif pada 5 Oktober, 1957 di Kuala Lumpur. Antara lain, beliau menekankan beberapa kualiti unggul yang perlu dimiliki oleh setiap pegawai awam seperti berikut: 
...First among these qualities I would place truthfulness... A good administrator and leader must be at pains not to leave any incorrect impression whatsoever upon the minds of his superiors;... second is qualities of clarity and precision. The good admnistrator should not waste his time trying to discuss what is at the back of someone else's mind;...Third, the good administor must display the quality of calm. The quality must displayed in two ways. In the first place he should be good tempered or at least be able to keep ill temper under control. In the second place he should be very patient especially with subordinate officers...Fourth, the quality of modesty. Lack of this quality may at some crucial issue, prevent him from confessing that his recommendations were incorrect.... One quality amongst others that must be avoided at all cost is self-satisfaction... Government officer to be able to forget his own opinion in order to place himself in the position of the member of the public whom he is serving, or the Head of Department.... Last is the quality of loyalty to the country and to the Government he serves. It is the quality can produce the spirit of teamwork and co-operation so necessary for good government servant....

... If I have made no mention of such qualities of honesty, integrity, courage, preseverance, sincerity, willingness to work, it is not because I consider them un-important. It is because that I have taken it for granted that you possess them. ${ }^{24}$

Jika dikaji ucapan tersebut secara mendalam dengan jelas mencerminkan betapa tingginya harapan Tunku untuk memantapkan integriti dalam perkhidmatan awam. Tunku sedar bahawa peranan dan tanggungjawab yang dipikul oleh perkhidmatan awam untuk meningkatkan kualiti hidup masyarakat berbilang bangsa amat mencabar. Perkhidmatan awam hanya dapat mencapai matlamat tersebut sekiranya setiap anggota perkhidmatan awam memiliki dan menghayati kualiti unggul yang mencerminkan integriti.

Selain itu, Tunku menggunakan majlis bersama Kongres Kesatuan Pekerja-pekerja Dalam Perkhidmatan Awam dan Jabatan Kerajaan (CUEPACS) untuk menekankan agenda integriti yang perlu dipelihara antara kerajaan dengan CUEPACS untuk meningkatkan kualiti pegawai perkhidmatan awam yang secara langsung membantu melaksanakan rancangan pembangunan bagi kepentingan rakyat. Ketika menyampaikan Ucapan Perasmian Konvensyen Tahunan CUEPACS Yang Kedua, Tunku menegaskan seperti berikut:

...in short existence CUEPACS has proved itself a responsible and well organised body... There is much to be gained by the Government Unions co-operating closely with one another...with the help, the government has been able to plan with confidence and... all its plans are successfully implemented... ${ }^{25}$ 
Dalam ucapan sama, Tunku telah mengingatkan semua kakitangan dan pegawai kerajaan supaya mengurangkan karenah 'red tape'. ${ }^{26}$ Pengamalan karenah birokrasi boleh melambatkan proses pelaksanaan rancangan pembangunan negara dan ini boleh membawa kepada pengamalan rasuah dalam perkhidmatan awam. Keadaan ini boleh mengancam dan memusnahkan matlamat kerajaan.

Berdasarkan huraian di atas, jelas bahawa Tunku ingin mewarisi sebuah jentera perkhidmatan awam yang berintegriti kerana pada awal kemerdekaan penglibatan dan sumbangan sektor swasta kepada pembangunan negara adalah terbatas. Jentera perkhidmatan awam terpaksa berfungsi sebagai nadi penggerak rancangan pembangunan negara ${ }^{27}$ dan berperanan untuk menstruktur semula kehidupan masyarakat luar bandar. ${ }^{28}$ Untuk mencapai matlamat tersebut, kerajaan pimpinan Tunku memilih individu yang berwibawa dan mempunyai kemahiran untuk menganggotai jabatan kerajaan. Tunku juga secara peribadi melantik pegawai perkhidmatan awam yang mempunyai kualiti unggul untuk mengetuai pelaksanaan rancangan kerajaan yang mengutamakan perpaduan dan patriotisme bagi membina imej negara dalam kalangan masyarakat tempatan dan antarabangsa.

\section{Pemilihan Pegawai Perkhidmatan}

Menjelang kemerdekaan, kerajaan pimpinan Tunku telah memberikan keutamaan kepada usaha membina imej negara. ${ }^{29}$ Ini penting untuk menarik pelabur dan memberikan imej baik kepada dunia. Tunku telah mengambil langkah awal untuk membina imej negara yang boleh membantu meningkatkan kepercayaan rakyat terhadap kepimpinannya. Untuk itu, Tunku melantik pegawai-pegawai yang cekap dan berpengalaman dalam perkhidmatan awam untuk melaksanakan rancangan pembangunan negara.

Tunku menggunakan kaedah tersendiri untuk menaikkan pangkat atau melantik right man for the right job. ${ }^{30}$ Untuk memenuhi kehendaknya, Tunku menganjurkan majlis makan malam untuk pegawai-pegawai kanan dan menteri dan mereka diminta hadir bersama isteri masingmasing. Majlis tersebut akan membantu Tunku memerhati dan mengenal pasti sama ada pasangan suami isteri hidup gembira atau bermasalah atau adakah isteri pegawai memakai barang-barang emas yang menampakkan pasangan tersebut hidup mewah. Bagi Tunku, kedua-dua situasi itu boleh menjejaskan perkhidmatan yang berkualiti dan mengancam pembangunan negara. Pegawai bermasalah tidak boleh menjalankan tugas dengan penuh tanggungjawab manakala pegawai yang hidup mewah pula akan menyalahgunakan kuasa untuk kepentingannya. Sebagai pemimpin yang bertanggungjawab, Tunku 
memanggil pegawai-pegawai yang mempunyai masalah rumah tangga untuk diberi nasihat tanpa menjejaskan hubungan dengan mereka. Sekiranya terbukti ada pegawai yang telah menyalahgunakan kuasa dan menerima rasuah maka tindakan akan diambil dengan menukarkan mereka ke tempat lain atau tidak dinaikkan pangkat. ${ }^{31}$ Bagi Tunku, pegawai kerajaan mesti mempunyai sifat ketaatsetiaan kepada negara, kepercayaan dan keyakinan.

\section{Pelantikan Pegawai Berwibawa Dalam Perkhidmatan Awam}

Pegawai berwibawa memainkan peranan yang sangat penting dalam perkhidmatan awam. Oleh itu, Tunku telah melantik Hamzah Dolmat, pemain muzik biola (violin) dan penyanyi lagu-lagu asli pujaan ramai yang terkenal di Singapura untuk bertugas di Radio Malaya. ${ }^{32}$ Sejak Hamzah dilantik di Radio Malaya, beliau memimpin Orkestra Radio dan mengadakan persembahan dalam program yang dianjurkan oleh kerajaan dan di majlis khas untuk meraih tetamu-tetamu luar negara. Usaha Tunku ini bertujuan untuk membina imej baik negara dalam majlis rasmi. Usaha ini berjaya kerana di bawah kepimpinan Hamzah Dolmat, persembahan dalam majlis rasmi lebih bermutu dan dapat mewujudkan tanggapan baik duta-duta asing mengenai negara Malaysia.

Selain itu, Tunku melantik Dol Ramli, Ketua Bahagian Perkhidmatan Melayu Radio Malaya (1956-1960) untuk menganjurkan pertandingan mencipta lagu kebangsaan. Beliau dilantik berasaskan pengalaman dan kejayaan beliau menyusun Jabatan Penyiaran bagi mengisi kemerdekaan, terutama sekali untuk memastikan mesej kerajaan sampai kepada rakyat. ${ }^{33}$ Sebagai Ketua Menteri, Tunku telah membuat ketetapan agar sebuah lagu kebangsaan dicipta sebelum hari kemerdekaan. Justeru itu, Dol Ramli yang mempunyai pengalaman dalam bidang penyiaran di arah untuk menganjurkan satu pertandingan mencipta lagu kebangsaan. Menurut Dol Ramli:

...Tunku told me, he wanted Radio Malaya to organise a nationwide competition to select a suitable tune to be used as national anthem for a country on the brink of political independence... ${ }^{34}$

Hasil pertandingan itu, sebanyak 514 buah lagu diterima tetapi tidak sebuah pun sesuai untuk dijadikan sebagai lagu kebangsaan. ${ }^{35}$ Berasaskan keputusan Jawatankuasa Pertandingan, semua lagu negeri yang sedia ada telah didengari dan akhirnya Tunku memilih lagu kebesaran negeri Perak iaitu 'Terang Bulan' untuk dijadikan sebagai lagu kebangsaan negara. Dengan kerjasama pegawai-pegawai Radio Malaya seperti Dol Ramli, Ahmad Merican dan Syed Nasir, 
Pengarah Dewan Bahasa dan Pustaka, Tunku telah membuat sedikit pengubahsuaian kepada lagu asal dan dijadikan lagu kebangsaan yang digelar sebagai Lagu Negara ku. ${ }^{36}$ Pemilihan pegawai yang cekap dan berwibawa dalam perkhidmatan awam terutama sekali dalam bidang penyiaran telah membantu penciptaan lagu kebangsaan yang menjadi pencetus untuk meningkatkan semangat kebangsaan dalam kalangan rakyat Malaysia.

\section{Peranan Stesen Suara Malaysia}

Untuk meningkatkan imej negara di peringkat antarabangsa, Tunku dengan kerjasama dan sokongan Dol Ramli, Ketua Penyiaran Radio Malaysia telah menubuhkan Stesen Suara Malaysia (Voice of Malaysia) di Radio Malaysia pada 16 September 1963. Salah satu faktor yang mendorong Tunku untuk menubuhkan stesen ini ialah untuk membetulkan persepsi masyarakat Indonesia dan antarabangsa mengenai keadaan dan cara hidup masyarakat di negara ini. ${ }^{37}$ Tunku sedar bahawa sebarang persepsi negatif mengenai keadaan negara, terutama sekali dalam kalangan negara-negara jiran boleh meninggalkan kesan buruk terhadap imej dan pembangunan negara.

Justeru itu, Tunku mengambil tindakan proaktif untuk menubuhkan stesen Suara Malaysia sebagai alat komunikasi antarabangsa untuk membetulkan pandangan masyarakat antarabangsa mengenai keadaan negara ini. Pegawai dan kakitangan yang ditempatkan di stesen ini telah menyampaikan berita dan menyiarkan rancangan-rancangan berbentuk hiburan yang bertemakan Truly Malaysian serta maklumat tentang sistem politik, ekonomi dan sosial termasuk berita sukan. ${ }^{38} \mathrm{Di}$ samping itu, temuramah yang dibuat dengan wakil-wakil dari negaranegara asing yang melawat Malaysia juga disiarkan. Pada peringkat permulaan, stesen Suara Malaysia hanya menyiarkan program dalam tiga bahasa; iaitu, Bahasa Indonesia, Mandarin dan Bahasa Inggeris tetapi menjelang tahun 1978 telah menambahkan siaran dalam bahasa Thai, Arab, Burma, Filipina dan Bahasa Malaysia-khusus untuk pelajarpelajar dan orang awam di New Zealand, Australia dan Eropah. ${ }^{39}$ Tunku juga telah melantik beberapa orang Indonesia yang tinggal di kawasan Lembah Klang, yang mempunyai pengalaman, kelayakan akademik dan kemahiran bertutur untuk berkhidmat di bawah seksyen Indonesia di rangkaian Suara Malaysia. Usaha ini adalah untuk meningkatkan kefahaman mengenai kehidupan masyarakat Malaysia yang sebenar kepada masyarakat Indonesia. ${ }^{40}$

Penubuhan stesen Suara Malaysia merupakan satu lagi kejayaan kerajaan Tunku untuk membina imej negara dalam kalangan masyarakat tempatan dan di peringkat antarabangsa. Kejayaan Tunku 
dalam memprojekkan imej positif tentang negara melalui stesen Suara Malaysia dapat dicapai melalui kerjasama dan komitmen dalam kalangan pegawai-pegawai yang berwibawa dan berintegriti dalam perkhidmatan awam. Berasaskan perbincangan, jelas usaha awal Tunku telah meletakkan asas bagi pembentukan jentera perkhidmatan awam yang berkualiti.

\section{Wanita Dalam Perkhidmatan Awam}

Tunku telah memberikan kedudukan adil dan saksama kepada golongan wanita dalam perkhidmatan awam. Ketika Tanah Melayu di bawah penjajahan British, golongan wanita tidak menerima layanan yang baik khususnya pelantikan dalam perkhidmatan awam. Menurut F. R. Bhupalan ${ }^{41}$ dalam tulisannya berjudul, "Indefatigable Proponent of Women's Right and Justice", bilangan pekerja wanita dalam sektor awam adalah terhad dan hanya terdapat seorang wanita dalam Malayan Civil Service (M.C.S) yang bertugas sebagai pegawai kontrak selama tiga tahun. Di samping itu, pegawai wanita dalam perkhidmatan awam yang sudah mendirikan rumah tangga diminta meletakkan jawatan dan kemudian dilantik semula sebagai pegawai sementara. Walaupun sebilangan besar pegawai wanita ditempatkan dalam profesion perguruan dan jururawat yang mempunyai kelayakan akademik yang sama dan menjalankan tugas yang sama seperti kaum lelaki tetapi gaji yang dibayar adalah lebih rendah berbanding kaum lelaki. ${ }^{42}$ Tunku sebagai seorang pemimpin yang bertanggungjawab dan menghormati hak asasi manusia, telah bertindak untuk memartabatkan kedudukan wanita dalam semua bidang termasuk perkhidmatan awam.

Dalam hal ini, Tunku berpendapat kaum lelaki dan wanita mempunyai peranan dan tanggungjawab yang sama untuk membangunkan negara dan kedua golongan ini mesti mendapat layanan dan pengiktirafan yang sama berasaskan kelayakan akademik dan pengalaman. Dalam hal ini, beliau berpegang teguh kepada Perlembagaan Persekutuan. Dalam Perkara 8, Perlembagaan Persekutuan, di bawah tajuk kesamarataan, antara lain menjelaskan bahawa semua orang adalah sama rata di sisi undang-undang dan berhak mendapat perlindungan yang sama rata di sisi undang-undang. Berasaskan pendirian tersebut, pada 14 Sepetmebr 1962, Tunku melantik Aishah Ghani (Tan Sri) sebagai Senator Wanita pertama. ${ }^{43}$ Di samping itu, syor-syor yang dikemukakan oleh (Tun) Fatimah Hashim ${ }^{44}$ Presiden, Majlis Kebangsaan Pertubuhan-Pertubuhan Wanita atau NCWO ${ }^{45}$ juga telah membantu mengubah sikap pemimpin terhadap keupayaan dan nilai peranan wanita dalam pelbagai bidang. ${ }^{46}$ Kerajaan pimpinan 
Tunku telah melaksanakan dasar equal pay for equal work. Menurut Tun Fatimah Hashim:

...we proposed that women in the public sector should be paid the same salary as men for perfoming the same jobs. Tunku agreed, and the Cabinet accepted it in principle. However, this was implemented only in $1970 \ldots$ later on, the private sector also follow suit... ${ }^{47}$

Perkara tersebut juga dikongsi bersama oleh F.R. Bhupalan seperti berikut:

...Tunku then set the ball rolling and when the time was ripe, we had won our struggle- Equal Pay For Equal Work. Today women were employed in large numbers; many hold high-ranking, responsible positions in the Government and Private Sectors.... The old colonial policy of discrimination against women has ended and it is Tunku who was responsible for its early demise. $^{48}$

Hasil komitmen kerajaan pimpinan Tunku, Suruhanjaya Perkhidmatan Awam yang dibentuk di bawah Perkara 144(1), Perlembagaan Persekutuan, mempunyai kuasa untuk melantik, mengesahkan dan menempatkan pegawai-pegawai yang berkelayakan dan berkaliber tanpa mengamalkan diskriminasi gender dalam perkhidmatan awam. ${ }^{49}$ Kerjasama dan sokongan yang diterima oleh kerajaan Tunku dari kaum wanita telah membantu meningkatkan jumlah pegawai wanita yang memegang jawatan penting dalam sektor perkhidmatan awam dan swasta. ${ }^{50}$ Dasar yang adil dan saksama ini telah menggerakkan perkhidmatan awam untuk menjadi peneraju rancangan pembangunan negara. Usaha Tunku memberikan wanita kedudukan yang sama dengan lelaki dari segi menambahkan pengalaman, pemberian gaji yang sama rata telah menghapuskan diskriminasi gender. Ini adalah satu lagi usaha penerapan integriti dalam perkhidmatan awam.

\section{Peneraju Rancangan Pembangunan Negara}

Kerajaan pimpinan Tunku telah memberi amanah dan tanggungjawab untuk merancang dan melaksana rancangan pembangunan kepada jentera perkhidmatan awam dengan sepenuhnya. Ini kerana, sektor swasta tidak dapat memberikan sumbangan berkesan disebabkan oleh pelaburan dan ekuiti dalam sektor swasta masih dikuasai oleh pelabur asing. ${ }^{51}$ Perancangan dan pelaksanaan rancangan pembangunan negara merupakan agenda terpenting kerajaan Tunku memandangkan sebilangan besar penduduk yang tinggal di kawasan luar bandar berada dalam paras kemiskinan dan ini mendesak kerajaan untuk 
melaksanakan rancangan pembangunan dengan segera. ${ }^{52}$ Ini jelas apabila meninjau kenyataan Tunku seperti berikut:

...rancangan Kerajaan terbahagi kepada dua bahagian yang besar. Bahagian pertama ialah kemajuan bandar yang tidak payah berbelanja besar. Ini kerana orang dalam bandar ialah orang kaya... Kemajuan yang begitu cepat berlaku dalam bandar yang terjadi dengan sendirinya dan dengan pertolongan daripada kerajaan boleh meninggalkan jauh orang yang hidup di luar bandar. Oleh sebab itu, dasar besar kerajaan Persekutuan dalam bahagian kedua ialah menguntukkan segala wang ringgit dan tenaga untuk membaikkan kehidupan orang kampung. ${ }^{53}$

Untuk mencapai matlamat tersebut, kerajaan memperkenalkan Rancangan Pembangunan Lima Tahun. Rancangan Pertama dilaksanakan di antara tahun 1956-1960, diikuti dengan Rancangan Malaya Kedua, 1961-1965 dan Rancangan Malaysia Pertama pada 1965-1970. ${ }^{54}$ Tunku melantik Tun Abdul Razak, Timbalan Perdana Menteri sebagai Menteri Pembangunan Luar Bandar pada tahun 1959, untuk memastikan rancangan pembangunan luar bandar berjalan dengan lancar. Tun Abdul Razak telah memainkan peranan penting untuk menjalinkan hubungan yang baik dengan kakitangan kerajaan. Beliau memberi motivasi dan meningkatkan semangat dalam kalangan pegawai dan kakitangan kerajaan supaya menumpukan sepenuh tenaga bagi melaksanakan program rancangan pembangunan luar bandar. ${ }^{55}$ Suasana mesra, tolong-menolong dan bekerjasama yang diwujudkan oleh pimpinan kerajaan dalam kalangan kakitangan dan pegawai kerajaan meningkatkan semangat untuk merancang, melaksana dan memantau rancangan pembangunan luar bandar di peringkat negara, negeri dan daerah dengan teratur. ${ }^{56}$ Tugasan murni yang dijalankan oleh perkhidmatan awam diakui oleh Tunku seperti berikut:

...jentera perkhidmatan awam juga telah mengerakkan tenaganya untuk membersihkan kawasan hutan untuk membina sekolah, klinik kesihatan, menyediakan kemudahan lampu elektrik dan membina jalan raya. ${ }^{57}$

Selain itu, menjelang tahun 1965, lebih daripada 800,000 ekar tanah pertanian telah diusahakan oleh pengusaha tanah pertanian. ${ }^{58}$ Kerjasama baik yang wujud antara pemimpin politik dan kakitangan kerajaan memberi kesan kepada peningkatan pendapatan negara. Dalam hal ini, menurut Tunku:

...hasil daripada pentadbiran kerajaan yang cekap, dalam masa dua tahun selepas merdeka, kerajaan telah dapat simpan kelebihan 
perolehan negeri sebanyak kira-kira RM20 juta, iaitu satu perkara yang luar biasa yang jarang berlaku dalam mana-mana negeri lain. ${ }^{59}$

Kualiti unggul yang telah sebati dalam perkhidmatan awam telah membantu kerajaan melaksanakan rancangan pembangunan kebangsaan dengan jayanya. Kejayaan itu disambut baik oleh Tunku seperti berikut:

\begin{abstract}
...like to take this oppurtunity before the House of paying tribute to the many hundreds of Government Officers throughout the whole country- technical, administrative and executive, wherever they may be-for the great part that they have played and continue to play in helping the Government to build a prosperous and stable nation through the implementation of our National Development Plan. ${ }^{60}$
\end{abstract}

Persefahaman dan kerjasama erat yang diwujudkan antara kerajaan dan pegawai-pegawai perkhidmatan awam telah membantu meningkatkan perbelanjaan pembangunan. Antara tahun 1957-1965, kerajaan telah membelanjakan sejumlah RM1.04 bilion dan antara tahun 1966 sehingga 1970 sejumlah RM4.55 bilion telah diperuntukkan bagi membiayai program-program pembangunan meliputi bidang sosial, infrastruktur dan ekonomi. ${ }^{61}$ Peningkatan perbelanjaan ini telah menarik pelabur asing, sektor swasta, pengusaha perlombongan bijih timah dan getah untuk meneruskan aktiviti perniagaan mereka di Malaysia. ${ }^{62}$ Pertumbuhan yang sihat ini membantu kerajaan untuk membuka lebih banyak kawasan perindustrian baru, memperkenalkan dasar pengecualian cukai selama lima tahun pertama kepada pelabur-pelabur asing dan memberi kebebasan untuk melantik pegawai pengurusan serta pekerja daripada luar negara. ${ }^{63}$

Kemajuan rancangan pembangunan dan pertambahan pelaburan dalam dan luar negara menyebabkan kerajaan mengambil langkah untuk mempertingkatkan kecekapan dan keberkesanan dalam perkhidmatan awam. ${ }^{64}$ Sistem penyampaian birokrasi yang melibatkan banyak proses dan mengambil masa yang panjang untuk membuat keputusan tidak sesuai dan tidak membantu kerajaan pimpinan Tunku untuk melaksanakan rancangan pembangunan bagi kepentingan rakyat dengan segera. ${ }^{65}$ Justeru itu, kerajaan pimpinan Tunku memperlihatkan pemodenan pentadbiran awam sebagai langkah terbaik untuk meningkatkan kecekapan dan keberkesanan perkhidmatan awam. ${ }^{66}$ Untuk mencapai matlamat tersebut kerajaan melantik dua perunding luar negara untuk mengkaji dan memberi cadangan bagi memantapkan kualiti kepimpinan dalam perkhidmatan awam. ${ }^{67}$ 


\section{Pengukuhan Integriti Dalam Perkhidmatan Awam}

Perkembangan pesat dalam pembangunan sosio ekonomi mendorong kerajaan pimpinan Tunku mengambil langkah untuk memodenkan perkhidmatan awam. Pemodenan ${ }^{68}$ perkhidmatan awam merupakan satu langkah untuk memperbaiki sistem pentadbiran dan meningkatkan kecekapan serta kualiti kepimpinan pentadbiran dalam perkhidmatan awam yang mencerminkan integriti bagi keperluan negara yang sedang pesat membangun. ${ }^{69}$ Untuk mencapai matlamat ini, kerajaan dengan kerjasama Yayasan Ford, melantik dua pakar runding dalam bidang pentadbiran awam ialah Profesor John D. Montgomery dari Universiti Harvard dan Profesor Milton J. Esman dari Universiti Pittsburgh. ${ }^{70}$ Pelantikan mereka adalah untuk menyemak, mengkaji dan membentangkan cadangan penambahbaikan berbentuk inovatif ${ }^{71}$ supaya dapat membentuk development administration yang cekap dan mempunyai kualiti kepimpinan yang unggul dalam perkhidmatan awam. $^{72}$

Kerajaan pimpinan Tunku mengambil langkah pembaharuan tersebut kerana corak pentadbiran dalam perkhidmatan awam yang sedia ada iaitu, maintenance administration yang popular dengan kerja-kerja rutin, tidak sesuai dan berkesan bagi merancang dan menggerakkan rancangan pembangunan. Tambahan pula, sistem tersebut tidak mewujudkan peluang untuk mempelajari dan memiliki kepakaran dalam bidang penyelarasan, perancangan dan pelaksanaan rancangan pembangunan. ${ }^{73}$ Ini terbukti berasaskan kaji selidik dan temu duga yang dibuat di peringkat awal penubuhan Development Administration Unit (DAU) ${ }^{74}$ (Bahagian Kemajuan Pentadbiran) bersama ketua-ketua jabatan dan pegawai-pegawai kanan yang bertanggungjawab mengendalikan kursus dan latihan di peringkat kementerian dan jabatan serta di peringkat kerajaan negeri. Dapatan kajian menunjukkan kursus dan latihan pembangunan tidak diberikan kepada semua kakitangan dan pegawai perkhidmatan awam dan latihan formal yang dirancang untuk kemajuan kakitangan dan pegawai juga tidak dikendalikan dengan sempurna.

Menurutnya lagi, hanya sebilangan kecil pegawai diberi insentif untuk melanjutkan pengajian bagi meningkatkan kemahiran. ${ }^{75}$ Bilangan itu adalah terhad dan tidak berupaya untuk melaksanakan rancangan pembangunan dengan sempurna. ${ }^{76}$ Kelemahan tersebut menyebabkan kerja-kerja perancangan dan pelaksanaan rancangan pembangunan mengambil masa yang panjang dan menelan perbelanjaan tinggi. ${ }^{77}$ Untuk menangani masalah ini, kerajaan melantik dua pakar runding dari Amerika Syarikat untuk membuat cadangan pemodenan perkhidmatan $a_{w a m}{ }^{78}$ yang mampu menjadikan Malaysia sebagai sebuah negara yang 
bersifat developmentalist. ${ }^{79}$ Ketika menyentuh tentang pelantikan dua pakar perunding, Tun Razak dalam ucapannya menyebut:

...It is gratifying to note that our public service is one of the best in the developing countries in the region but there is room still for improvement... For this reason the Government has invited a two man team of public administration experts provided by the Ford Foundation to make the recommendations for increasing efficiency and performance in the development administration of the country. ${ }^{80}$

Pada tahun 1965, Profesor John D. Montogomery dan Profesor Milton J. Esman telah membentangkan laporan pemodenan pentadbiran pembangunan kepada kerajaan Malaysia. ${ }^{81}$ Melalui langkah pemodenan perkhidmatan awam, kerajaan bertekad untuk memantapkan integriti dalam perkhidmatan awam. Ini dapat dilihat apabila meneliti dua daripada bidang utama yang diperakukan oleh kerajaan berasaskan Laporan Montogomery-Esman; iaitu pembentukan DAU di Jabatan Perdana Menteri dan memperbaiki program pendidikan dan latihan kerajaan bagi semua peringkat perkhidmatan awam. ${ }^{82}$

Berasaskan Laporan Montogomery-Esman, kerajaan telah menubuhkan DAU di bawah Jabatan Perdana Menteri pada 1 Julai 1966 dan berfungsi sebagai unit pusat yang merancang dan membimbing pelaksanaan penambahbaikan dalam pentadbiran awam. ${ }^{83} \mathrm{DAU}$ juga berperanan sebagai penyelaras dan membantu kementerian serta pentadbiran negeri dan tempatan untuk memperbaiki sistem prosedur yang lapuk, merancang aktiviti, sistem belanjawan dan pengurusan kewangan kerajaan Persekutuan, pengurusan personel dan sistem pentadbiran tanah di peringkat negeri. ${ }^{84}$ Pegawai-pegawai DAU yang berkelulusan dalam bidang pengurusan kewangan dan pentadbiran awam daripada universiti Amerika Syarikat, berperanan sebagai pembimbing dan penasihat kepada jabatan-jabatan kerajaan untuk merancang dan melaksanakan aktiviti- aktiviti penambahbaikan pengurusan perkhidmatan awam. ${ }^{85}$

Sebelum penubuhan DAU, tidak ada satu unit di bawah kerajaan pusat untuk memimpin dan memantau program-program kerjaya untuk meningkatkan produktiviti staf dan pegawai. ${ }^{86}$ Pegawai dan kakitangan yang dipertanggungjawabkan untuk merancang dan melaksana projek pembangunan pula tidak mempunyai pengetahuan dan pengalaman dan mereka hanya dilatih untuk menjalankan kerja-kerja rutin. Akibatnya berlaku isu-isu yang menjejaskan kualiti perkhidmatan seperti yang dijelaskan oleh Tun Razak dalam tujuh penyakit kronik. Ini menyebabkan pelaksanaan rancangan pembangunan luar bandar tidak mengikut jadual, mengambil masa yang panjang dan menelan 
perbelanjaan yang besar. ${ }^{87}$ Penubuhan DAU merupakan satu langkah murni kerajaan pimpinan Tunku untuk mempertingkatkan kualiti perkhidmatan dan kualiti kepimpinan yang mencerminkan integriti dalam perkhidmatan awam. Selepas penubuhan DAU, kerajaan telah memberi fokus untuk memperbaiki rancangan pendidikan dan latihan kerajaan untuk semua peringkat perkhidmatan berasaskan perakuan kedua Laporan Montogemery-Esman. ${ }^{88}$

Penerimaan perakuan untuk memperbaiki program pendidikan dan latihan kerajaan untuk semua peringkat perkhidmatan jelas menampakkan keikhlasan kerajaan Tunku untuk meningkatkan kualiti, kemahiran, pengetahuan dan tingkah laku dalam kalangan pegawai perkhidmatan awam, yang secara langsung meningkatkan mutu kerja perkhidmatan awam yang mencerminkan integriti. ${ }^{89}$ Ini kerana program pendidikan dan latihan membimbing pegawai dan kakitangan untuk meningkatkan lagi pengetahuan, kemahiran dan kaedah terbaru pelaksanaan rancangan kerja harian untuk kepentingan rakyat. ${ }^{90} \mathrm{Di}$ samping itu, ia juga membantu pegawai dan kakitangan untuk menilai keupayaan dan kelemahan masing-masing yang membantu memajukan mutu perkhidmatan.

Kerajaan memperkenalkan post-entry program dalam bidang pembangunan pentadbiran di Universiti Malaya kepada pegawaipegawai kanan yang baru dilantik. Langkah ini bertujuan untuk melatih dan memantapkan pengetahuan pegawai-pegawai dalam bidang pentadbiran awam supaya dapat menyampaikan perkhidmatan cemerlang kepada rakyat. ${ }^{91}$ Program pendidikan dan latihan juga diperkenalkan kepada pegawai-pegawai yang sudah lama berkhidmat dalam perkhidmatan awam supaya mereka boleh meningkatkan pengetahuan dalam bidang pentadbiran dan mempelajari pendekatan baru pelaksanaan rancangan pembangunan. Di samping itu, program latihan dalam perkhidmatan juga diperluaskan kepada kakitangan dalam bidang teknikal dan pembantu tadbir pejabat. Untuk memelihara kualiti dan keberkesanan program pendidikan dan latihan untuk semua peringkat pegawai dan kakitangan perkhidmatan awam, kerajaan menubuhkan Jabatan Latihan dan Pembangunan Kerjaya di Jabatan Perkhidmatan Awam. Dalam masa yang sama, kerajaan menukarkan nama Pusat Latihan Kakitangan kepada Institut Tadbiran Awam (INTAN) pada tahun 1972, untuk mencerminkan langkah-langkah positif yang diambil oleh kerajaan adalah untuk membangunkan modal insan yang berkualiti. ${ }^{92}$

Dengan perluasan program pendidikan dan latihan di peringkat universiti dan pengendalian latihan dalam perkhidmatan yang tersusun, setiap individu dalam perkhidmatan awam telah meningkatkan pengetahuan dan kemahiran dalam bidang tugasan harian masing- 
masing. Ini membimbing mereka untuk berperanan sebagai penyelesai masalah dan pembuat keputusan yang bijak ${ }^{93}$ berasaskan integriti bagi kepentingan rakyat dan negara. Dengan ini, organisasi perkhidmatan awam dan kepimpinan kerajaan memperoleh manfaat daripada pegawai dan kakitangan yang mengikuti latihan. ${ }^{94}$ Penambahbaikan yang dilaksanakan dalam program pendidikan dan latihan dalam perkhidmatan awam berasaskan Laporan Montogomery-Esman, jelas menunjukkan komitmen kerajaan pimpinan Tunku untuk membentuk sistem perkhidmatan awam yang berintegriti.

Berdasarkan huraian di atas, jelas Laporan MontogomeryEsman merupakan satu titik rujuk yang penting dalam reformasi sistem perkhidmatan awam yang telah mengubah corak pentadbiran penyelenggaraan kepada pentadbiran ke arah pembangunan negara yang secara langsung mengukuhkan integriti dalam perkhidmatan awam. ${ }^{95}$

\section{Laporan Suruhanjaya Taylor}

Pada tahun 1950, kerajaan British telah menubuhkan sebuah Suruhanjaya penyiasatan yang dipengerusikan E.N. Taylor bagi meninjau integriti dalam kalangan kakitangan perkhidmatan awam. Salah seorang ahli Suruhanjaya Taylor ialah Tun Hussein Onn, Perdana Menteri Malaysia yang ketiga. ${ }^{96}$ Berasaskan penyiasatan, pada tahun 1955, Suruhanjaya Taylor telah membentangkan tiga puluh satu cadangan kepada kerajaan. ${ }^{97}$ Antara cadangan yang dikemukakan termasuk langkah-langkah menyeragamkan Perintah Am yang berkaitan dengan kelakuan dan disiplin dalam perkhidmatan awam, tindakan undangundang terhadap kes-kes rasuah dan membuat pindaan kepada undang-undang yang berkaitan dengan Ordinan Pencegahan Rasuah. ${ }^{98}$ Selepas memenangi pilihan raya pada tahun 1955, pada tahun 1956, Tunku memperkenalkan Peraturan-Peraturan Pegawai Awam untuk meningkatkan disiplin dan tingkah laku pegawai dan kakitangan perkhidmatan awam. Selepas negara mencapai kemerdekaan, peraturan-peraturan tersebut telah melalui beberapa perubahan selaras dengan kehendak semasa. Perubahan pertama berlaku pada tahun 1968; kemudian pada tahun 1980 dan sehingga kini. Pindaan terakhir ialah Peraturan-Peraturan Pegawai Awam (Kelakuan dan Tatatertib) 1993, P.U.(A) 246 (Pindaan 2002) yang merupakan sumber peraturan utama yang mengawal disiplin penjawat awam di Malaysia. Tindakan tatatertib boleh diambil sekiranya pegawai kerajaan melanggar sebarang peraturan yang ditetapkan. ${ }^{99}$ 


\section{Penerapan Integriti Melalui Peraturan-Peraturan Pegawai Awam}

Kejayaan Tunku dalam menerapkan integriti dalam perkhidmatan awam terserlah apabila wujudnya satu bab khusus mengenai Peraturan-Peraturan Pegawai Awam (Kelakuan dan Tatatertib) dalam perkhidmatan awam. Bab tersebut diwujudkan untuk meningkatkan semangat pegawai awam melaksanakan tugas dengan cekap, amanah dan bertanggungjawab. Di samping itu, setiap pegawai perlu meletakkan kepentingan awam daripada kepentingan sendiri dalam menjaga imej perkhidmatan awam. Dengan adanya peraturan tersebut, ia menjadi panduan dan membimbing setiap anggota perkhidmatan awam untuk memperbaiki tingkah laku. ${ }^{100}$ Pematuhan peraturan kelakuan dan tatatertib merupakan satu tanggungjawab dan kewajipan bagi setiap kakitangan perkhidmatan awam. Jika gagal atau enggan mematuhinya, boleh dikenakan tindakan tatatertib. ${ }^{101}$ Dengan adanya kakitangan yang mematuhi peraturan, kerajaan dapat mengekalkan paras produktiviti yang tinggi dengan kos yang munasabah. ${ }^{102}$

Pindaan yang dibuat dalam Peraturan-Peraturan Pegawai Awam (Kelakuan dan Tatatertib) 1956, telah meningkatkan imej dan integriti dalam perkhidmatan awam. Contoh ketara dalam hal ini ialah perubahan peraturan-peraturan yang diperkenalkan pada tahun 1969. Pada tahun tersebut peraturan diubahsuai dan digantikan dengan PeraturanPeraturan Pegawai Awam (Kelakuan dan Tatatertib), Perintah Am Bab D, 1969 yang memperuntukkan larangan dalam menerima hadiah atau keraian. Dalam hal ini, seseorang kakitangan kerajaan dilarang untuk memberi atau menerima apa jua bentuk hadiah atau keraian termasuk bagi anak dan isteri.

Pemberian hadiah kepada kakitangan perkhidmatan awam oleh individu-individu tertentu mungkin mempunyai kepentingan dari aspek perkhidmatan. Perbuatan tersebut boleh menjejaskan akauntabiliti, kredibiliti dan integriti kakitangan dan seterusnya mencemarkan jentera perkhidmatan awam. Justeru itu, peruntukan peraturan yang menghalang kakitangan kerajaan sama ada memberi atau menerima hadiah atau keraian membuktikan kesungguhan kerajaan untuk mencegah berlakunya rasuah ${ }^{103}$ dan memartabatkan integriti dalam perkhidmatan awam. Jika wujud keadaan, di mana seseorang kakitangan sukar untuk menolak sesuatu hadiah bernilai, yang dilarang oleh peraturan ini maka hadiah itu bolehlah diterima secara rasmi dengan cara mengemukakan laporan bertulis kepada Ketua Jabatan. Pindaan ini yang dibuat mengikut kehendak dan peredaran masa merupakan satu tindakan bijak untuk mempertingkatkan kredibiliti dan integriti dalam perkhidmatan awam. ${ }^{104}$ 
Dapatlah dirumuskan pelaksanaan Peraturan-peraturan Pegawai Awam (Kelakuan dan Tatatertib) 1956 merupakan satu mekanisme terawal yang diperkenalkan oleh pemimpin tempatan untuk menjaga imej perkhidmatan awam. Dengan wujudnya peraturan ini, telah meningkatkan kesedaran dan menjadi panduan kepada kakitangan perkhidmatan awam untuk memperbaiki tingkah laku dan meningkatkan kecekapan serta mengurangkan karenah birokrasi dalam perkhidmatan awam. Kewujudan Peraturan-Peraturan Pegawai Awam, menunjukkan kesungguhan Tunku untuk menangani isu-isu rasuah dalam perkhidmatan awam. Ini terbukti apabila pada tahun 1958, Tunku melantik Shah Nazir Alam, Pegawai Tinggi Polis, Cawangan Khas, Pasukan Polis Pakistanuntuk membuat tinjauan dan mengemukakan cadangan serta perakuan bagi mengatasi dan mencegah perbuatan rasuah daripada terus merebak dalam perkhidmatan awam. ${ }^{105}$

\section{Kesimpulan}

Tunku telah memainkan peranan penting dalam memantapkan integriti dalam perkhidmatan awam pada era pemerintahan beliau. Kejayaan tersebut sebahagian besarnya bertolak daripada keperibadian Tunku yang mendokong integriti sejak alam persekolahan dan ia lebih terserlah sewaktu beliau berkhidmat sebagai Pegawai Daerah di Kulim, Kedah dan apabila beliau menjadi pemimpin UMNO. Integriti diterjemahkan dalam tindakan apabila beliau menjadi Perdana Menteri Persekutuan Tanah Melayu.

Langkah pertama yang diambil oleh Tunku untuk memantapkan perkhidmatan awam ialah dengan menubuhkan Suruhanjaya Perkhidmatan Awam pada 1957 dan ini diikuti dengan tindakan peribadi untuk memilih pegawai perkhidmatan awam yang berwibawa untuk membina imej negara. Ini dilakukan dengan menyusun kepimpinan RTM bagi menyampaikan mesej kerajaan secara berkesan kepada rakyat dan penubuhan stesen Suara Malaysia bagi meningkatkan imej Malaysia di persada antarabangsa. Tunku juga menggunakan majlis rasmi sebagai mekanisme untuk menyemak integriti pegawai awam.

Tunku juga telah bertindak menggunakan perkhidmatan awam untuk membangunkan rancangan pembangunan negara. Ini dapat diperhatikan apabila beliau berjaya melaksanakan rancangan pembangunan lima tahun melalui Rancangan Malaya Pertama dan Kedua (1956-65) dan Rancangan Malaysia Pertama, 1965-70. Usaha juga diambil untuk memberi ruang kepada wanita untuk memainkan peranan yang dominan dalam perkhidmatan awam.

Tunku juga telah mengambil tindakan pentadbiran untuk memastikan perkhidmatan awam berintegriti. Ini dilakukan dengan 
melantik pakar untuk menyemak keberkesanan perkhidmatan awam yang membawa kepada penghasilan Laporan Montogomery-Esman dan Laporan Suruhanjaya Taylor sebagai asas pembentukan peraturanperaturan pegawai awam. Kemuncak usaha Tunku untuk meningkatkan integriti dalam perkhidmatan awam adalah usaha mencegah rasuah dalam perkhidmatan awam dengan menjemput Shah Nazir Alam dari Pakistan untuk meninjau masalah rasuah dalam perkhidmatan awam. Semua perkembangan ini dengan jelas membuktikan bahawa Tunku telah meletakkan batu asas bagi memantapkan integriti dalam perkhidmatan awam dalam era pemerintahan beliau.

\section{Nota}

1 Perkhidmatan awam Tanah Melayu bermula dengan penubuhan Malaya Establishment Office yang seterusnya membawa kepada penubuhan Malayan Establishment Office (MEO) pada 1934 dengan tugas untuk mengadakan perubahan dalam peraturan dan syarat-syarat perkhidmatan serta rayuan yang berkaitan. MEO dibubarkan pada 1954 dan digantikan dengan Federation Establishment Office pada 1 Julai 1954 dengan tugas mengawal perkhidmatan awam dalam hal-hal skim, syarat-syarat perkhidmatan, tangga gaji, perjawatan dan organisasi, hal-hal perkhidmatan, persaraan dan pencen. Mulai 1 Julai 1967, FEO juga bertanggungjawab dalam halhal kenaikan pangkat dan disiplin. Pada tahun yang sama FEO ditukar menjadi Establishment Office Malaysia (EOM). Pada 15 Ogos 1968, nama EOM ditukar menjadi Jabatan Perkhidmatan Awam (Panduan Rekod-Rekod Persekutuan Arkib Negara Malaysia, 1992, hlm. 294-295).

$2 \quad$ Kathirthamby-Wells, "Early Singapore And The Inception Of A British Administrative Tradition In The Straits Settlements (1819-1832), dalam Journal Of The Malaysian Branch Royal Asiatic Society (JMBRAS), Volume 42, Part 2, December 1969, hlm. 74.

3 Robert Huessler, British Rule in Malaya: The Malayan Civil Service and Its Predecessors, 1867-1942, London: Clio Press, 1981, hlm. 30-31.

$4 \quad$ Emily Sadka, Protected Malay States, Kuala Lumpur: Universiti Malaya Press, 1968, hlm. 59.

$5 \quad$ Ibid., hlm. 375.

6 Sivachandralingam Sundara Raja, "The Federation Scheme of 1895 And Capital Penetration In The Federated Malay States", dalam Malaysia in History, Kuala Lumpur: Malaysian Historical Society, Vol. 29, 2005, hlm. 64.

7 Khasnor Johan, 'The Malay College, Kuala Kangsar, 1905-1941: British Policy Of Education For Employment in the Federated Malay States', Latihan Ilmiah sebagai memenuhi syarat bagi memperoleh Ijazah Sarjana Sastera, Jabatan Sejarah, Fakulti Sastera dan Sains Sosial, Universiti Malaya 1969, hlm. 20.

8 Report of a Commission to Enquire into Matters Affecting the Integrity of the Public Services, 1955, Kuala Lumpur, Pencetak Kerajaan, Persekutuan Tanah Melayu, 1955, hlm. 1. 
9 Report of a Commission to Enquire into Matters Affecting the Integrity of the Public Services, 1955, Kuala Lumpur, Pencetak Kerajaan, Persekutuan Tanah Melayu, 1955, hlm.3.

10 Perlembagaan Malaysia yang juga dikenali sebagai Perlembagaan Persekutuan mengandungi 183 perkara, dan merupakan undangundang tertinggi di Malaysia. Perlembagaan ini merupakan satu dokumen undang-undang bertulis yang telah dibentuk berasaskan dua dokumen terdahulu iaitu Perjanjian Persekutuan Tanah Melayu 1948 dan Perlembagaan Kemerdekaan tahun 1957. Dipetik daripada wikipedia org/wiki/Perlembagaan_Malaysia. 20 April 2010.

11 Abdul Aziz Zakaria, Jentera Pentadbiran Kerajaan Di Malaysia : Suatu Pengenalan, Kuala Lumpur, Dewan Bahasa dan Pustaka, 1987, hlm. 33.

12 Peranan dan Fungsi Unit Penyelarasan Suatu Analisis Penggerak Jentera Pentadbiran, Kuala Lumpur, Unit Penyelarasan Pelaksanaan Jabatan Perdana Menteri dan Institut Kajian Sejarah dan Patrotisme Malaysia, hlm. 40.

Mavis Puthucheary, The Politics of Administration The Malaysian Experience, Petaling Jaya: Oxford University Press, 1978, hlm. 39. Fungsi SPA ialah untuk menguruskan pelantikan anggota Perkhidmatan Awam, mengesahkan anggota Perkhidmatan Awam dalam perkhidmatan, menguruskan pemberian taraf berpencen kepada anggota Perkhidmatan Awam, berfungsi sebagai Lembaga Kenaikan Pangkat bagi kenaikan pangkat, berkuasa menukar anggota Perkhidmatan Awam dari satu skim perkhidmatan ke satu perkhidmatan yang lain dan menjalankan tanggungjawab tatatertib dengan membuang kerja atau menurunkan pangkat ke atas pegawai-pegawai Kumpulan Pengurusan Tertinggi dan Kumpulan Pengurusan dan Profesional. Untuk keterangan lanjut sila rujuk Perkara 144(1), Tugas-tugas Suruhanjaya Perkhidmatan, Perlembagaan Persekutuan, hlm. 101.

Tunku Abdul Rahman Putra, Looking Back, Kuala Lumpur: Pustaka Antara, 1977, hlm. 60. Ucapan Tunku Abdul Rahman, di Majlis Perundangan Persekutuan, pada 10 Julai 1957 dalam Ucapan-ucapan Tunku Abdul Rahman Putera 1959 dan 1960, Kuala Lumpur: Arkib Negara Malaysia, 1985, hlm. 59.

Robert O. Tilman, The Public Services of The Federation of Malaya, Durham: Duke University, 1961, hlm. 59. Ucapan Tunku Abdul Rahman sebagai Ketua Menteri dalam Sidang Akhbar yang diadakan di Kuala Lumpur, pada 28 Ogos 1957 dalam Ucapan-ucapan Tunku Abdul Rahman Putera 1959 dan 1960, hlm. 74. Abdul Rahman Abdul Aziz dan Mustapa Kassim, Amanat Presiden Demi Agama, Bangsa dan Negara, Kuala Lumpur: Berita Publishing Sdn. Bhd., hlm. 129. Report of the Public Services Commission Federation of Malaya For The Years 1957 and 1958, Kuala Lumpur: Percetakan Kerajaan, 1960, hlm. 16 dan 17. Laporan Tahunan Suruhanjaya Perkhidmatan Awam Malaysia 2008, Kuala Lumpur, Percetakan Kerajaan, 2009.

22 Robert O. Tilman, The Public Services of The Federation of Malaya, hlm. 222. 
Ucapan Tunku Abdul Rahman, di Majlis Perundangan Persekutuan, pada 10 Julai 1957 dalam Ucapan-ucapan Tunku Abdul Rahman Putera 1959 dan 196, hlm. 59 dan 60.

Ucapan Ketua Menteri Kepada Pegawai Perkhidmatan Awam Dalam Majlis Perundangan Persekutuan Kuala Lumpur, pada 10 Julai, 1957, dalam Koleksi Ucapan Tunku Abdul Rahman Putra, 1950 - 1960, hlm. 140 dan 141.

Ucapan Ketua Menteri Dalam Majlis Perasmian Konvensyen Tahunan Cuepacs Yang Ke-Dua, di Kuala Lumpur, Pada 10 September 1960, dalam Koleksi Ucapan Tunku Abdul Rahman Putra, 1950 - 1960, hlm. 127 dan 128. Ibid., hlm. 129.

$27 \quad$ Peranan dan Fungsi Unit Penyelarasan Pelaksanaan Suatu Analisis Penggerak Jentera Pembangunan, Kuala Lumpur, Unit Penyelarasan Pelaksanaan Jabatan Perdana Menteri dan Institut Kajian Sejarah dan Ptrotisme Malaysia, hlm .40.

Shamsul Amri Baharuddin, "Perancangan Pembangunan Negara Selepas Merdeka 1957-1975: Tinjauan Sejarah Perkembangan Sosio- Ekonomi Malaysia", dalam Khoo Kay Kim dan Jazamuddin Baharuddin, Malaysia: Sejarah dan Proses Pembangunan, Kuala Lumpur, Persatuan Sejarah Malaysia, 1979, hlm. 338.

Haji Dol Ramli, "The Tunku and I", dalam Prabhakaran Nair, Recollections and Reflections on Tunku Abdul Rahman, Kuala Lumpur: Arkib Negara Malaysia, hlm. 195. Yap Chin Kwee, "Tunku, The Tragic Hero", dalam Prabhakaran Nair, Prince Among Men, Kuala Lumpur, Arkib Negara Malaysia, 2006, hlm. 341. Ibid., hlm. 342. Haji Dol Ramli, “The Tunku and I", hlm. 195. Idris Musa, “Dol Ramli, Tokoh Yang Dikagumi, Bekas Ketua Pengarah Penyiaran Main Peranan Penting Susun Pelbagai Program Dalam Mengisi Kemerdekaan" Harian Metro, 27 Januari 2011. Ibid., hlm. 196-197. http:/ / ms.wikipedia.org/wiki/Lagu_Negaraku. 10 Januari 2011. Haji Dol Ramli, "The Tunku and I" , hlm. 196 dan 197. Zulkarnain Mohd. Mess, "Voice of Malaysia: Malaysia's International Radio Service", dibentang dalam Persidangan International Shortwave Broadcasting In Asia and The Pacific, Singapura, 1986, hlm. 1.

38 Ibid., hlm. 2.

$39 \quad$ Ibid., hlm. 3 dan 4.

40 Ibid., hlm. 197.

41 Rasammah Naomi Navarednam @ Mrs F.R. Bhupalan, dilahirkan pada tahun 1927 dan selepas menamatkan pengajian di Universiti Malaya, beliau berkhidmat sebagai guru di Sekolah Methodist (Lelaki), Kuala Lumpur antara tahun 1959 hingga 1964. Kemudian dilantik sebagai pengetua di Sekolah Methodist (Perempuan), Kuala Lumpur antara tahun 1970 sehingga bersara pada tahun 1982. Beliau terkenal sebagai pejuang hak asasi wanita melalui Majlis Kebangsaan Pertubuhan- 
Pertubuhan Wanita Malaysia (NCWO), Prabhakaran Nair, Prince Among Men, Kuala Lumpur: Arkib Negara Malaysia, 2006, hlm. 257.

F. R. Bhupalan, "Indefatigable Proponent of Women's Right and Justice", dalam Prabhakaran Nair, Prince Among Men, Kuala Lumpur: Arkib Negara Malaysia, 2006, hlm. 261.

43 Fatimah Hashim, "Tunku-The Architect Of Our Independence", dalam Prabhakaran Nair, Prince Among Men, Kuala Lumpur, Arkib Negara Malaysia, 2006, hlm. 59.

44 (Tun) Fatimah Hashim dilahirkan pada 1924, di Muar, Johor. Beliau menerima pendidikan awal di Sekolah Melayu Lelaki Parit Keroma, Muar. Kemudian menyambung pelajarannya di Sekolah Melayu Perempuan Mersing. Selepas tamat pengajian, beliau berkhidmat sebagai guru dan berminat dalam kerja-kerja kebajikan. Fatimah memulakan kerjaya politiknya dengan menyertai UMNO pada tahun 1947 dan mulai tahun 1956, beliau menjadi Ketua Pergerakan Kaum Ibu negeri Perak dan dalam masa yang sama, memegang jawatan Ketua Bahagian Ipoh. Dalam tahun yang sama, beliau telah dilantik sebagai Ketua Pergerakan Kaum Ibu Malaya. Pada 25 Ogos 1963, beliau menubuhkan Majlis Kebangsaan Pertubuhan - Pertubuhan Wanita atau National Council of Women's' Organization- NCWO dan dilantik sebagai Presiden pertama. Selama 14 tahun, beliau berkhidmat sebagai Ahli Parlimen dan di antara tahun 19691973, beliau menjadi Menteri Kabinet (Tun Fatimah Hashim, “Tunku-The Architect Of Our Independence", dalam Prabhakaran Nair, Prince Among Men, hlm. 53).

Majlis Kebangsaan Pertubuhan - Pertubuhan Wanita atau NCWO merupakan satu gabungan pertubuhan-pertubuhan sukarela wanita seluruh Malaysia yang berupa satu badan penasihat, perunding dan juga advokasi mengenai isu-isu yang berkaitan dengan kemajuan wanita, (Fatimah Hamid Don, "Majlis Kebangsaan Pertubuhan- Pertubuhan Wanita Malaysia (NCWO)- Peranan dan Pencapaian : Suatu Tinjauan Sejarah", Kumpulan Kertas Kerja Seminar Penghayatan Dan Pengukuhan Kemerdekaan Malaysia (Jilid 2), Kuala Lumpur, Arkib Negara Malaysia dan Kementerian Kebudayaan, Keseniaan dan Pelancungan, 2000, hlm. 117. Ibid., hlm. 118.

47 Tun Fatimah Hashim, “Tunku - The Architect Of Our Independence, hlm. 59.

F. R. Bhupalan, "Indefatigable Proponent of Women's Right and Justice", hlm. 262.

49 Abdullah Sanusi Ahmad, Norma Mansor dan Abdul Kuddus Ahmad, The Malaysian Bureaucracy Four Decade of Development, Kuala Lumpur, Pearson Malaysia, hlm. 112.

50 Fatimah Hashim, "Tunku - The Architect Of Our Inpendence", hlm. 61.

51 Peranan dan Fungsi Unit Penyelarasan Pelaksanaan Suatu Analisis: Penggerak Jentera Pembangunan, hlm. 25. 
Abdul Rahman Abdul Aziz dan Mustapa Kassim, Amanat Presiden Demi Agama, Bangsa dan Negara 1957-1971, Kuala Lumpur: Berita Publishing Sdn. Bhd., hlm. 151.

53 Ibid., hlm. 204.

54 Matlamat Rancangan Malaysia Pertama ialah untuk meningkatkan pertumbuhan ekonomi melalui peningkatan pendapatan per kapita dan taraf hidup rakyat. Penekanan lebih diberikan kepada masyarakat luar bandar yang berpendapatan rendah seperti menyedia dan memperbaiki kemudahan asas di kawasan luar bandar di samping mempelbagaikan keluaran pertanian. Matlamat Rancangan Malaya Kedua ialah untuk meningkatkan pertumbuhan ekonomi dan taraf hidup rakyat menerusi kepelbagaian ekonomi dan pembangunan produk selain getah. Rancangan Malaysia Pertama merupakan rancangan pembangunan yang meliputi negeri-negeri Semenanjung Tanah Melayu, Sabah dan Sarawak untuk memupuk integrasi di kalangan penduduk semua negeri di Malaysia serta meningkatkan pertumbuhan ekonomi dan kebajikan rakyat, http://www. malaysiamerdeka.gov.my/v2/ms/pencapaian/ekonomi/121-rancanganmalaysia-1-9, 28 Ogos 2012. Ucapan Tun Abdul Razak di Majlis Pembukaan Mesyuarat R.I.D.A. yang pertama pada 22 Mac 1960, dalam Ucapan-ucapan Tun Haji Abdul Razak bin Hussein, Kuala Lumpur: Arkib Negara Malaysia, 1975, hlm. 38 dan 39. Ucapan oleh Timbalan Perdana Menteri Berkenaan Dengan Pembangunan Luar Bandar, Melalui Radio Malaya pada 7 September 1961, dalam Ucapan-ucapan Tun Abdul Razak bin Hussein, Kuala Lumpur: Arkib Negara Malaysia,1961, hlm. 214. Tunku Abdul Rahman Putra, Looking Back, hlm. 342. Hazizan Md Noon, "Development in Malaysia: An Overview", dalam Abdul Rashid Moten, Government and Politics in Malaysia, Singapore, Cengage Learning, 2008, hlm. 30. Abdul Rahman Abdul Aziz dan Mustapa Kassim, Amanat Presiden Demi Agama, Bangsa dan Negara- 1951-1971, hlm. 205. Ibid., hlm. 101 dan 102.

61 Rancangan Malaysia Kedua 1971-1975, Kuala Lumpur, Percetakan Kerajaan, 1971, hlm. 16. J. Kennedy, A History of Malaya, Kuala Lumpur, Synergy Media, 2007, hlm. 389.

$63 \quad$ Ibid., hlm. 390

64 Peranan dan Fungsi Unit Penyelarasan Pelaksanaan Suatu Analisis Penggerak Jentera Pembangunan, hlm. 49.

65 Milton J. Esman, Administration and Development in Malaysia Institution Building and Reform In a Plural Society, London: Cornell University Press, 1972, hlm. 135.

66 Peranan dan Fungsi Unit Penyelarasan Pelaksanaan Suatu Analisis Penggerak Jentera Pembangunan, hlm. 52.

67 Ahmad Atory Hussain, "Peranan Pentadbir dan Pembaharuan Pentadbiran Awam Dalam Mengisi dan Memperkukuhkan Kemerdekaan Negara: Penghayatan dan Cabaran", dalam Kumpulan Kertas Kerja Seminar 
Penghayatan Dan Pengukuhan Kemerdekaan Malaysia (Jilid 2), Kuala Lumpur, Arkib Negara Malaysia dan Kementerian Kebudayaan, Kesenian dan Pelancongan, 2000, hlm. 66.

Modenisasi dalam perkhidmatan awam bermaksud proses perubahan berterusan yang bertujuan untuk meningkatkan kecekapan dan keberkesanan perkhidmatan awam. Tugas ini dilakukan oleh Unit Pemodenan Tadbiran dan Perancangan Pengurusan (MAMPU) dan Jabatan Perdana Menteri. (Warisan Gemilang, Kumpulan Rencana, Pilihan Buletin INTAN 1976-1991, Kuala Lumpur: Institut Tadbiran Awam Negara, 1993, hlm. 171). Milton J. Esman, Administration and Development in Malaysia Institution Building and Reform In a Plural Society, hlm. 140. Perkhidmatan pakar runding tersebut dibayar oleh Yayasan Ford. Abdullah Sanusi Ahmad, Norma Mansor dan Abdul Kuddus Ahmad, The Malaysian Bureaucracy Four Decade of Development, hlm. 222.

John D. Montgomery dan Milton J. Esman, Development Administration In Malaysia -A Report To The Government of Malaysia., Kuala Lumpur: Percetakan Kerajaan, 1966, hlm. iii.

Milton J. Esman, Administration and Development in Malaysia Institution Building and Reform In a Plural Society, hlm. 8.

DAU ialah ringkasan kepada Development Administration Unit, yang diperakukan dalam Laporan Montgomery dan Esman, dalam John D. Montgomery dan Milton J. Esman, Development Administration In Malaysia -A Report To The Government of Malaysia. Ibid., hlm. 189.

Ibid., hlm. 139.

Peranan dan Fungsi Unit Penyelarasan Pelaksanaan Suatu Analisis Penggerak Jentera Pembangunan, hlm. 50.

$78 \quad$ Ibid., hlm. 42.

79 Ahmad Atory Hussein, Polisi dan Dasar Awam Malaysia, Kuala Lumpur, Utusan Publications \& Distributors Sdn.Bhd., 1990, hlm. 172.

Di petik daripada Ucapan Tun Abduk Razak, Timbalan Perdana Menetri, pada 19 Ogos 1965, ketika membentangkan perkara-perkara penting yang terkandung dalam Rancangan Malaysia Pertama kepada SetiausahaSetiausaha Tetap, Setiausaha Kementerian, Setiauasa Kerajaan Negeri, Setiausaha Kewangan Negeri, Pegawai-pegawai Pembangunan Negeri dan Ketua-ketua Jabatan Persekutuan, di Dewan Tunku Abdul Rahman, (Victor Morais, Strategy For Action, Kuala Lumpur: Jabatan Cetak Kerajaan, 1969, hlm. 197 dan 198). John D. Montogomery dan Milton J. Esman, Development Administration In Malaysia, hlm. 143 dan 144.

82 Ibid., hlm. vii.

83 Samsudin bin Osman, "General Trends and Reforms in the Malaysian Civil Service," dalam Intan Jurnal, Kuala Lumpur, Institut Tadbiran Awam Negara (INTAN), 1986, hlm. 42.

84 Milton J. Esman, Administration and Development in Malaysia Institution Building and Reform In a Plural Society, hlm.156. 
Ibid., hlm. 157.

Ibid., hlm. 187.

Peranan dan Fungsi Unit Penyelarasan Pelaksanaan Suatu Analisis Penggerak Jentera Pembangunan, hlm., 50.

Ibid., hlm. 54.

Samsudin bin Osman, "General Trends and Reforms in the Malaysian Civil Service", hlm. 43.

Ahmad Sarji bin Abdul Hamid, Upholding the Integrity of the Malaysian Civil Service, Kuala Lumpur: Pelanduk Publications, 1993.

Abdullah Sanusi Ahmad, Perkembangan Pentadbiran Awam dan Pengurusan, Koleksi Ceramah Umum, Kuala Lumpur: Dewan Bahasa dan Pustaka, Kementerian Pendidikan Malaysia, Cet. 1, 1994, hlm. 132.

Ibid., hlm. 133.

Ahmad Sarji bin Abdul Hamid, Upholding the Integrity of the Malaysian Civil Service, hlm. 39.

Abdullah Sanusi Ahmad, Norma Mansor dan Abdul Kuddus Ahmad, The Malaysian Bureaucracy Four Decade of Development, hlm. 127.

Samsudin bin Osman, "General Trends and Reforms in the Malaysian Civil Service," hlm. 44.

Ibid., hlm. 3 dan 4.

Terma rujukan Suruhanjaya Taylor ialah untuk meninjau kes-kes rasuah dalam perkhidmatan awam Persekutuan, reaksi dalam kalangan masyarakat awam terhadap perbuatan tersebut dan membentangkan cadangan untuk mengurang dan mencegah perbuatan rasuah. Untuk maklumat lanjut sila rujuk Report of a Commission to enquire into matters affecting the Integrity of The Public Services 1955, Kuala Lumpur, Percetakan Kerajaan, 1955, hlm. 3.

Ibid., hlm. 60- 62.

Samihah Khalil @ Halim, Siti Alida Kohn Abdullah, Rusniah Ahmad, Mohd Fo' ad Sakdan, Ahmad Martadha Mohamed, Noor Faizzah Dollah, Sakinah Muslim, Nur Syakiran Akmal Ismail, Kajian Keberkesanan Sistem Pengurusan Tatatertib Kakitangan Dalam Memperkukuhkan Integriti Perkhidmatan Awam, Alor Setar: Universiti Utara Malaysia, 2009, hlm. 2 dan 21.

Peraturan - Peraturan Pegawai Awam (Kelakuan \& Tatatertib) (1993) \& Pindaan 2002, (P.U.[A] 395).

Perintah-perintah Am dan Arahan Pentadbiran Hingga 15 Ogos 2007, Petaling Jaya: Selangor, International Law Book Services 2007, hlm. 149.

Pentadbiran dan Pengurusan Awam Malaysia, hlm. 344.

Perintah-perintah Am dan Arahan Pentadbiran Hingga 15 Ogos 2007, hlm. 153.

Badan Pencegah Rasuah Malaysia 1967-1992 Sejarah Penubuhan dan Perkembangannya, Kuala Lumpur: Ibu Pejabat Badan Pencegah Rasuah, Malaysia, 1992, hlm. 38.

105 Sukar untuk mendapatkan maklumat mengapa Shah Nazir Alam dilantik bagi memberikan cadangan bagi mencegah rasuah dalam perkhidmatan awam. Ia mungkin berasaskan hubungan yang sedia wujud dengan 
Pakistan apabila seorang wakil dari negara ini terlibat dalam pengubalan perlembagaan Malaysia. Maklumat yang sedia ada menyatakan beliau adalah Ketua Polis Punjab Selatan (1950) dan pengasas serta ketua Unit Pencegahan Rasuah Pakistan. 